\section{Regulation issue is resurrected by EPA}

\section{Washington}

GOVERNMENT regulation of genetic engineering is once again about to become a live issue. Regulation has steadily declined as the fears that prompted the creation, seven years ago, of the National Institutes of Health (NIH) Recombinant DNA Advisory Committee (RAC) have failed to materialize. But the Environmental Protection Agency (EPA) may change all that.

In a move fraught with legal complications, EPA is asserting regulatory authority over the commercial production of genetically-engineered microorganisms such as those designed to eat oil slicks that would be deliberately released into the environment.

EPA's action has revived questions about the adequacy of RAC's guidelines, which are not binding on industry, about the ability to assess the risks of novel organisms and about the legal grounds for Under the RAC guidelines, which are manrecipients of NIH research grants, prior permission is required for any deliberate release of genetically-engineered organisms. Industry as a whole has voluntarily agreed to adhere to the RAC guidelines, and several states and localities have passed laws making the guidelines mandatory.

Moreover, according to Geoffrey Karny of Congress's Office of Technology Assessment, tort law provides a strong incentive for industry to follow the guidelines. Should an injury claim arise in connection with a deliberately-released organism, non-negligence on the manufacturer's part would be adherence to the guidelines. "Any company would be foolish not to comply with them", he says.

RAC's continued willingness to serve as a quasi-regulatory body over industry may, however, wane as commercial applications grow. RAC's expertise has also been called into question when it comes to commercial use and to the ecological issues that pertain to environmental release. The RAC membership is largely molecular biologists and doctors. The major worry over environmental release of novel organisms is that they may find a new niche and become ineradicable pests, as has occurred with the introduction in the United States of such exotic plants and animals as the gypsy moth, chestnut blight and the kudzu vine. According to Karny, nearly half of the major insect pests in the United States, for example, originated abroad.

EPA has had a chance to get its feet wet in this area through its regulation of biological pest controls, which, under the Fedgovernment control of genetic engineering. datory only for government agencies and eral Insecticide, Fungicide, and Rodenticide Act (FIFRA) are considered to be pesticides; data on environmental fate and residues, performance and effects on nontarget organisms are required for approval under this act. EPA officials are now working on extending risk-assessment procedures to recombinant organisms - both pest controls and others.

Outside the agency, there is considerable scepticism over the value of research aimed at developing such risk-assessment methodology. Frances Sharples of Oak Ridge National Laboratory, who has examined the problem for EPA, says that although the analogy with microorganisms such as the gypsy moth is valid, nothing in the literature provides any basis for predicting whether a novel organism will be a problem or not. EPA at present has only a handful of scientists at work on the problem, although it is said to be planning a vastly expanded research effort over the next several years.

The legal basis for EPA's regulation is only slightly less uncertain than its scientific basis. Although biological pest controls are unquestionably under EPA's regulatory authority (under FIFRA), the status of other micro-organisms, such as the oil-eating bacteria, is less clear. EPA has determined that the non-pest control organisms, as they contain altered DNA, are "new chemical substances", and thus subject to the Toxic Substances Control Act (TSCA). EPA justifies this inter- pretation by reference to the act's legislative history, which shows a congressional intention that the law should cover all substances not already covered by the clean air, clean water or pesticide laws.

Under TSCA, a manufacturer must notify EPA 90 days before it intends to begin manufacture of a new substance and provide all available data on its safety. EPA has the choice then of requiring the manufacturer to conduct further safety tests or of regulating or even prohibiting the manufacture or use of the substance. The law does not cover research and development use of a new substance.

Karny says that while "it would be opening a real can of worms to challenge EPA" on its authority to regulate new organisms under TSCA, such a challenge "would not be off the walls"' legally. Thomas McGarity, a law professor at the University of Texas who has studied the issue, says that EPA's position is "convincing, albeit risky".

Yet industry may have little to gain from such a challenge. TSCA's requirements are fairly lenient, and a challenge, Karny says "'may raise questions about the companies' motives and could lead to more restrictive legislation" specifically directed at novel organisms. And, as Sharples points out, what the industry is looking for is some legal certainty from the government. "The industry is very paranoid", she says, about the legal pitfalls of going ahead with the use of manufactured organisms for such applications as enhanced oil recovery, mineral recovery or pollution clean-up. TSCA would of fer the advantage to the industry of familiar procedures and some well-defined boundaries. "The lack of those boundaries is translating into inaction", she says.

Stephen Budiansky

\section{US spending on research}

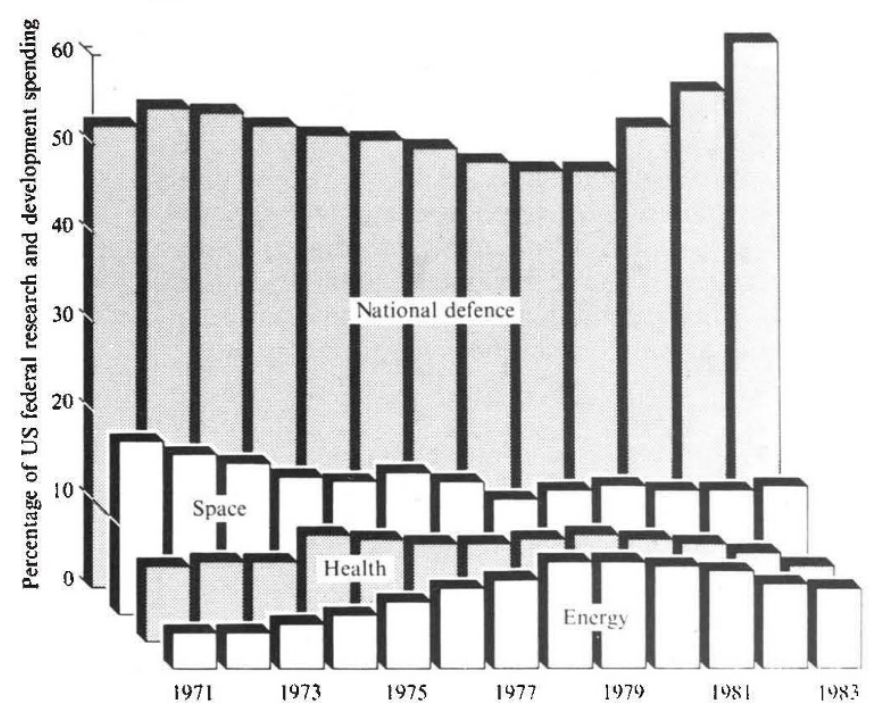

PERCENTAGE federal spending on US research and development of defence, space, health and energy. The increase in energy spending after 1973 reflects the increase in non-nuclear expenditure after the oil-price rise of 1973. Source: NSF Report on Federal R\&D Spending for Energy: Fiscal Years 1971-1984. 